\title{
The late Pleistocene-Holocene sedimentary facies and geotechnical properties of CLM1 core at Cao Lanh city Mekong river delta
}

- Truong Minh Hoang University of Science, VNU-HCM

- Nguyen Van Lap

- Ta Thi Kim Oanh

Vietnam Academy of Science and Technology, HCMC Institute of Resources Geography

- Takemura Jiro

Tokyo Institute of Technology, Japan

(Manuscript received on March $20^{\text {th }} 2012$, accepted on January $14^{\text {st }} 2013$ )

\section{ABSTRACT}

The aim of the study was to know a trend of mechanical behavior and geotechnical properties; applied for, calculating the mechanical behavior of the ground, planning the infrastructure, specially the traffic system and port, and building a rational investigated-procedure by combinations of in-situ tests, sampling and laboratory tests. Sedimentary environments of the CLM1 core at Caolanh city, Mekong River Delta (MRD) were reestablished based upon the deposit properties. Investigate the geotechnical properties and origin of the formation of them. CLM1 core site which has seven facies; each facies has presents a typical sequence of the geotechnical properties. Post-depositional processes have important role in formation of geotechnical properties.

Keywords: Pleistocene, Holocene, sediment, facies, natural levee, geotechnical properties, mechanical behavior

\section{INTRODUCTION}

The late Pleistocene-Holocene sediments continuously occurred in the MRD in the different sedimentary environments; simultaneously, the typically sedimentary properties were formed, and then they were subjected the changes in the post-depositional processes [1, 2]. The geotechnical engineering properties of the ground in the MRD are very complex [3]. Materials, structures, and changes of post-depositional processes influenced on the geotechnical engineering properties [4, 5]. Therefore, studying the changes of sedimentary environment and surveying the geotechnical engineering properties of the sedimentary facies at the Caolanh city, MRD, were carried out.

\section{INVESTIGATION PROGRAM}

In situ tests, boring and sampling

The investigation was carried out in the Caolanh City, northwest of the MRD (Fig. 1a). The borehole (designated CLM1) was located at latitude $10^{\circ} 27^{\prime} 39.50^{\prime \prime} \mathrm{N}$, longitude $105^{\circ} 38^{\prime}$ 20.00 " $\mathrm{E}$ at an altitude of $\mathrm{z}=+3.2 \mathrm{~m}$ above the present mean sea level and came to $\mathrm{z}=-39.0 \mathrm{~m}$. 
A thin-walled tube sampler with a fixed piston with specification of sampler, $2 \mathrm{~mm}$ thickness, $710 \mathrm{~cm}$ length, $85 \mathrm{~mm}$ inside diameter (Fig. 1e); fixed piston was pushed by water pressure. Soil samples were kept in the stainless steel tube sampler, enveloped by soft materials and contained in wooden boxes (Fig. 1f). The ground water level was $\mathrm{z}=+0.7 \mathrm{~m}$. Cone Penetration Test (CPTU) was conducted at the site using a piezo-cone penetrometer with friction sleeve. The cone penetrometer was pushed into ground using hydraulic type penetration machine, designated CPTU1-CL, was conducted to a depth of $z=-37$ $\mathrm{m}$, and the other, a Standard Penetration Test (SPT) was also carried out every $2 \mathrm{~m}$ to a depth of $\mathrm{z}=-40 \mathrm{~m}$. The plan layout of the borehole, CLM1, and the in situ tests are shown in Fig. 1b.

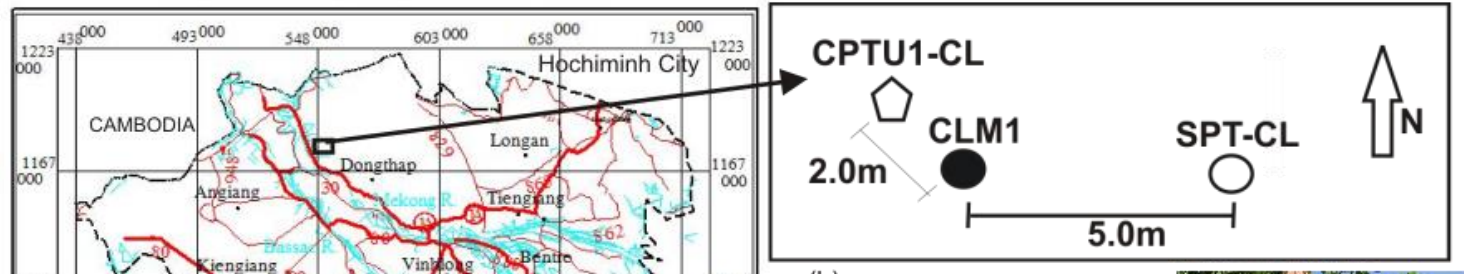

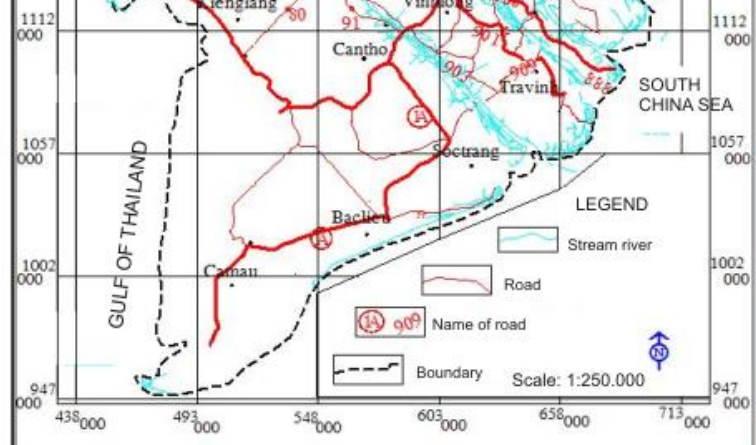

(a) SCALE: $1: 250.000$

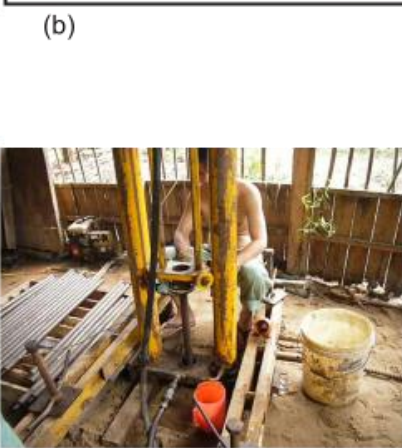

( c)

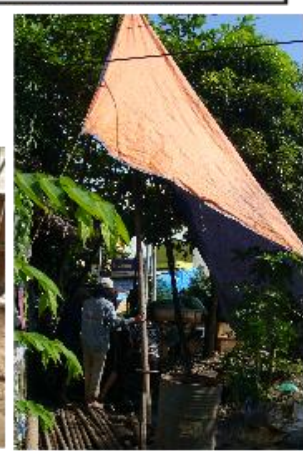

(d)
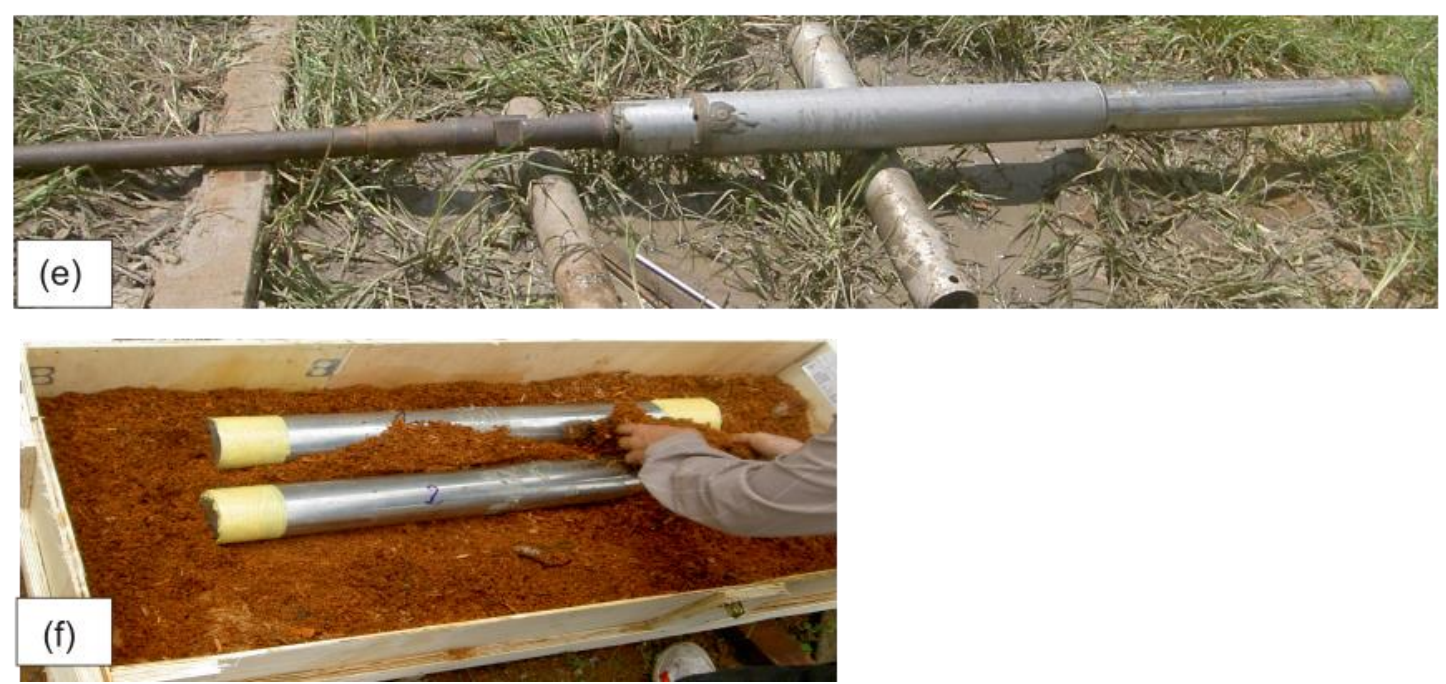

Fig.1. (a) Location of Caolanh investigation site on the map of the MRD. (b) Plan layout of CLM1 borehole, CPTU and SPT tests at the site. (c) Conducting CPTU1-CL. (d) Boring and sampling CLM1 and SPT-CL. (e) Stainless steel thin-walled tube sampler with a fixed piston. (f) Wet soft materials and wooden boxe contained tube samplers.

\section{Trang 30}




\section{LAB TESTS}

Various sedimentary structures and properties were conducted. Carbon isotope $\left({ }^{14} \mathrm{C}\right)$ dating of the organic material in some soil samples was performed by the Beta Analytic Radiocarbon Dating Lab, Japan. Basic geotechnical properties, such as grain size distribution, natural water content, $\mathrm{w}_{\mathrm{n}}$, plastic limit, $\mathrm{w}_{\mathrm{p}}$, liquid limit, $\mathrm{w}_{\mathrm{L}}$, unit weight, $\gamma_{\text {sat }}$, specific gravity, $G_{s}$, (Head, 1985a) [6], were obtained every $0.1 \mathrm{~m}$. The liquidity index, LI, was estimated from $\mathrm{w}_{\mathrm{n}}, \mathrm{w}_{\mathrm{p}}$, and $\mathrm{w}_{\mathrm{L}}$. On the other hand, vertical effective stress $\sigma_{v 0}^{\prime}$ was estimated from $\gamma_{\text {sat }}$. Unconfined compressive tests were conducted both for undisturbed soils and for remolded soil to obtain sensitivity, $\mathrm{S}_{\mathrm{t}}$. For evaluating one-dimensional consolidated properties, incremental loading oedometer tests (IL) (Head, 1985b) [7], were mainly conducted with undisturbed and reconstituted samples at the Engineering Geology Laboratory of Ho Chi Minh City University of Natural Science, Vietnam (HCMCUS). Constant rate of strain consolidation tests (CRS) (JGS, 2000) were also conducted on typical soil samples taken from each facies at Geomechanics Lab of Tokyo Institute of Technology and the Port and Airport Research Institute at Yokosuka, Japan. The yield stresses $\sigma_{y-I L}^{\prime}$ and $\sigma_{y-C R S}^{\prime}$ were estimated from the IL and CRS results. The yield stress ratio, OCR $\left(\sigma_{v y}^{z} / \sigma_{v o}^{\prime}\right)$, initial void ratio, $\mathrm{e}_{\mathrm{ivr}}$, in situ void ratio, $\mathrm{e}_{0}, \Delta \mathrm{e}=\mathrm{e}_{\mathrm{ivr}}-\mathrm{e}_{0}$, and $\Delta \mathrm{e} / \mathrm{e}_{\text {ivr }}$, were calculated.

\section{RESULTS}

Lithostratigraphy and inferred depositional facies

The stratigraphy and sedimentary environments of CLM1 core were rebuilt based on the characteristics of grain size, color, sedimentary structure, clay minerals, fossils and carbon isotope $\left({ }^{14} \mathrm{C}\right)$ ages of the sediments. The sediments of CLM1 core can be divided into seven lithostratigraphic units. Then, seven depositional facies are inferred based on the characteristics of the units and grain size fractions. The characteristics of these units, corresponding depositional facies are presented below in ascending order in Fig. 2.

\section{Results of geotechnical engineering tests}

\section{Results of in situ tests}

A typical soil profile can be estimated by soil-behavior-type classification using the following normalized values (Robertson 1990 and 1991) [8 - 9]:

Normalized cone resistance:

$$
Q_{t}=\frac{q_{t}-\sigma_{v o}}{\sigma_{v o}^{\prime}}
$$

Normalized friction ratio:

$$
F_{R}=\frac{f_{s}}{q_{t}-\sigma_{v o}} \times 100 \%
$$

Normalized pore pressure ratio:

$$
B_{q}=\frac{u-u_{o}}{q_{t}-\sigma_{v o}}
$$

Where $\sigma_{\mathrm{v} 0}$ and $\sigma^{\prime}{ }_{\mathrm{v} 0}$ are total and effective vertical stress. 


\begin{tabular}{|c|c|c|}
\hline $\begin{array}{l}\text { Altitude } \\
(\mathrm{m})\end{array}$ & Grain size & $\begin{array}{l}\text { Lithostratigraphic } \\
\text { unit }\end{array}$ \\
\hline
\end{tabular}

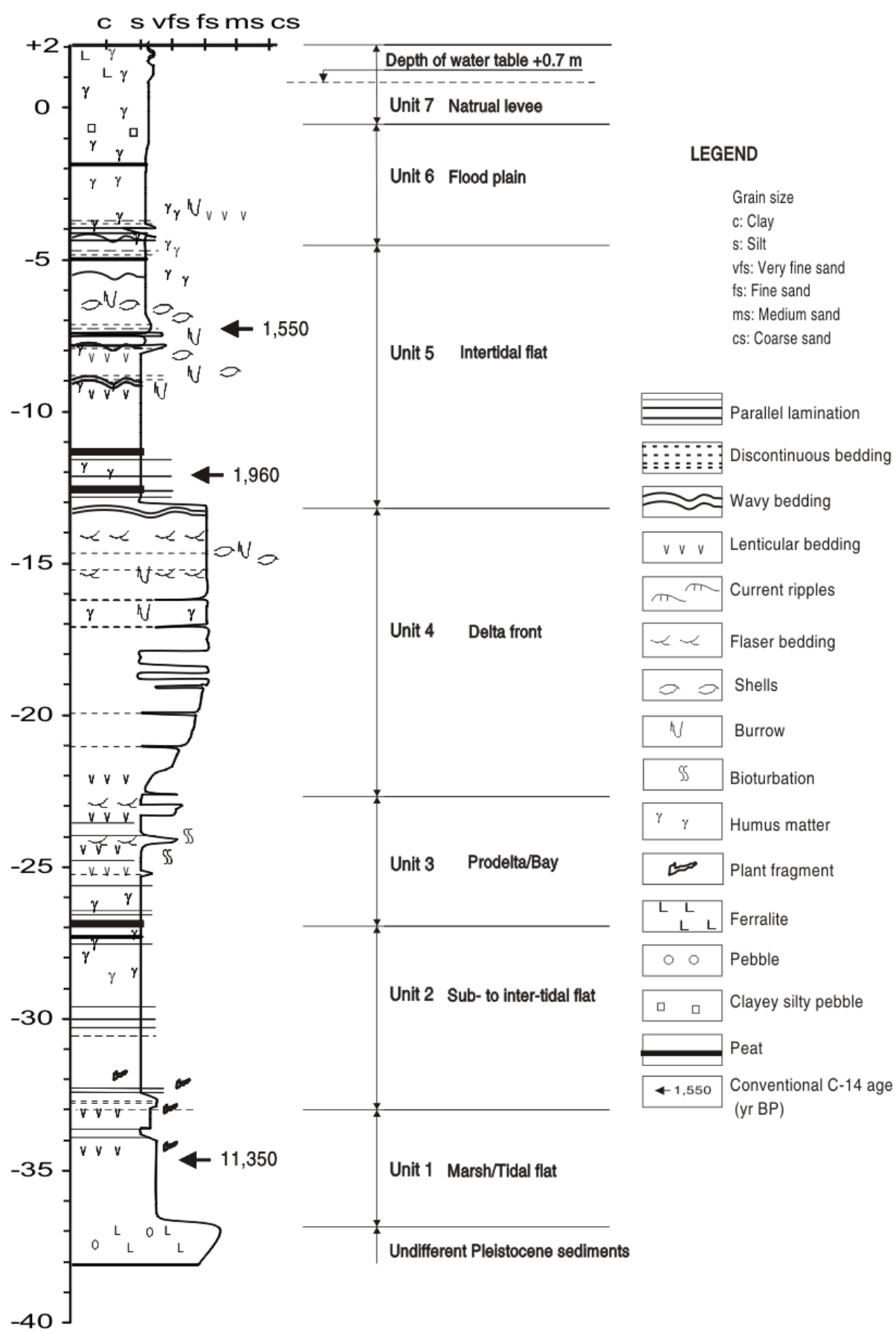

Fig. 2. Geological column of the CLM1 core and its correlation with lithostratigraphic units 
The soil-behavior types estimated from the relationship between $Q_{t}$ and $F_{R}$ (Robertson, 1990 and 1991) are shown in Fig. 3. The soil-behavior types estimated from the relationship between $\mathrm{Q}_{t}$ and $\mathrm{B}_{\mathrm{q}}$ (Robertson, 1991) were almost the same as those estimated from the $\mathrm{Q}_{\mathrm{t}}-\mathrm{F}_{\mathrm{R}}$ relationship. In the cohesive soil layers with homogeneous material properties, $Q_{t}, F_{R}$ and $B_{q}$ are all rather constant with depth.

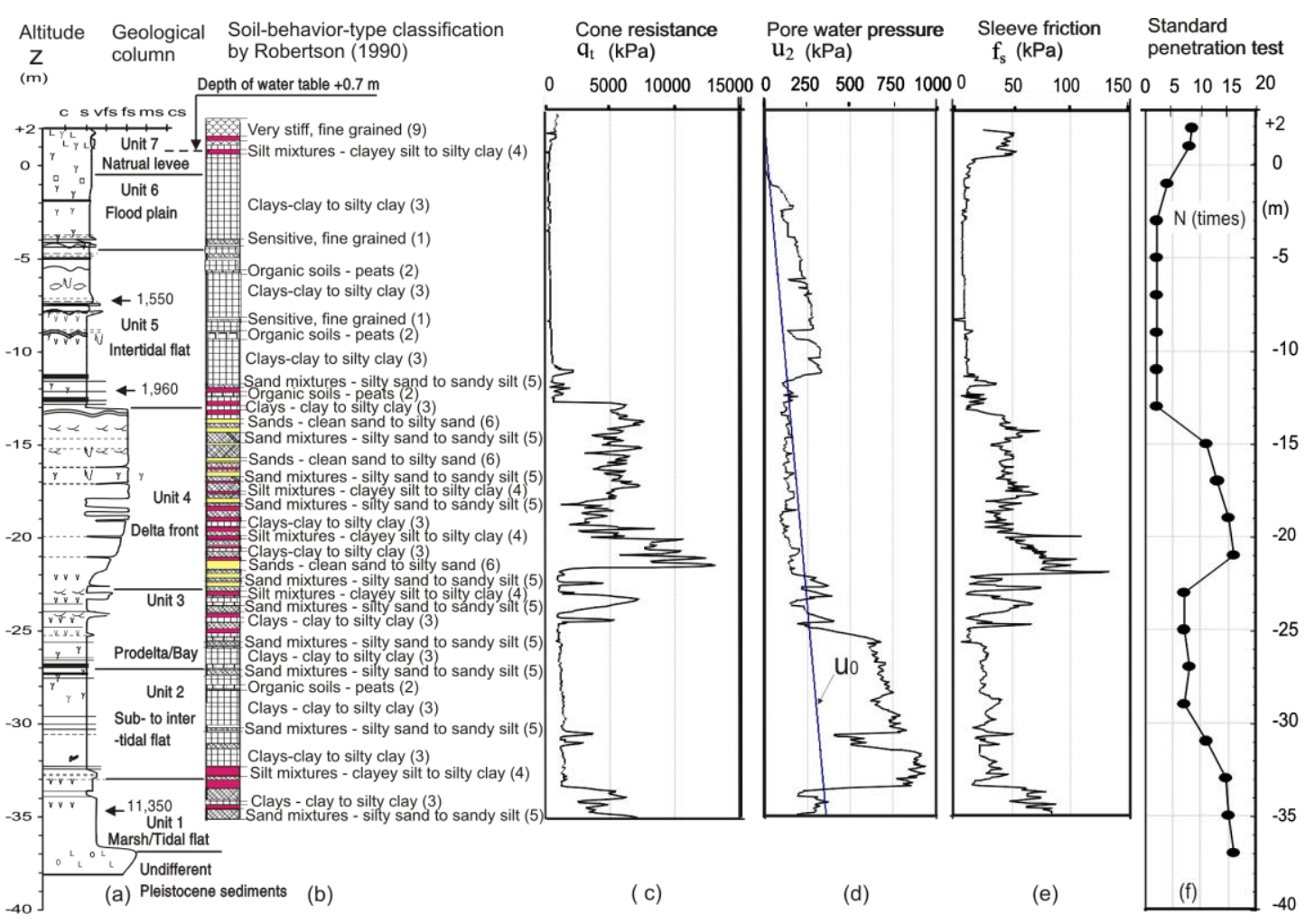

Fig. 3. CPTU1-CL, SPT-CL results of the in situ tests at the Caolanh site: (a) columnar section of the CLM1 core, (b) soil-behavior-type classification by $\mathrm{Q}_{t}$ and $\mathrm{F}_{\mathrm{R}}$ obtained from CPTU1-CL, (c) - (e) cone resistance, $\mathrm{q}_{t}$, pore water pressure, $\mathrm{u}_{2}$, and sleeve friction, $\mathrm{f}_{\mathrm{s}}$, of CPTU1-CL, (f) $\mathrm{N}$ value from the SPT-CL.

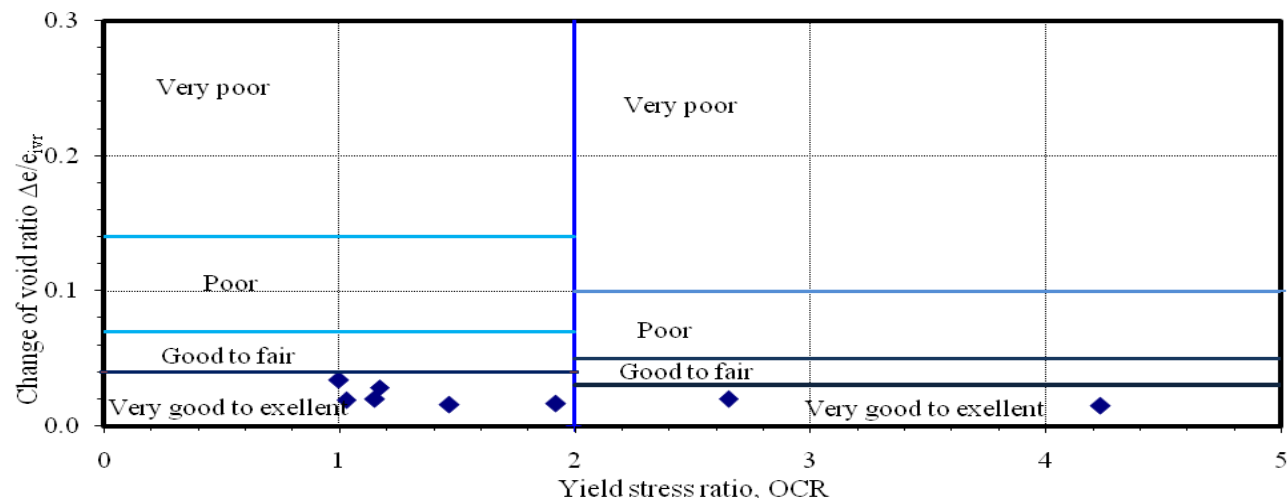

Fig. 4. Changes of void ratio due to recompression to the effective overburden stress from oedometer tests on Caolanh clay specimens. 


\section{Results of lab tests}

The quality of the Caolanh cohesive soil specimens were evaluated by the criteria of sample quality for cohesive soils of Andresen and Kolstad (1979) [10] and shown in Fig. 4.

Void indices $\mathrm{I}_{\mathrm{v} 0}$ for in situ void ratio $\mathrm{e}_{0}$ were estimated using equation (4) (Burland, 1990) [4],

$$
I_{\nu 0}=\frac{e_{0}-e_{100}^{*}}{e_{100}^{*}-e_{1000}^{*}}
$$

where $e_{100}^{*}$ and $e_{1000}^{*}$ are the void ratios of the intrinsic compression curve at $\sigma_{v}=100 \mathrm{kPa}$ and $1000 \mathrm{kPa}$, respectively. The intrinsic compression curve can be obtained from samples reconstituted at a water content of between $w \mathrm{~L}$ and $1.5 \mathrm{wL}$.

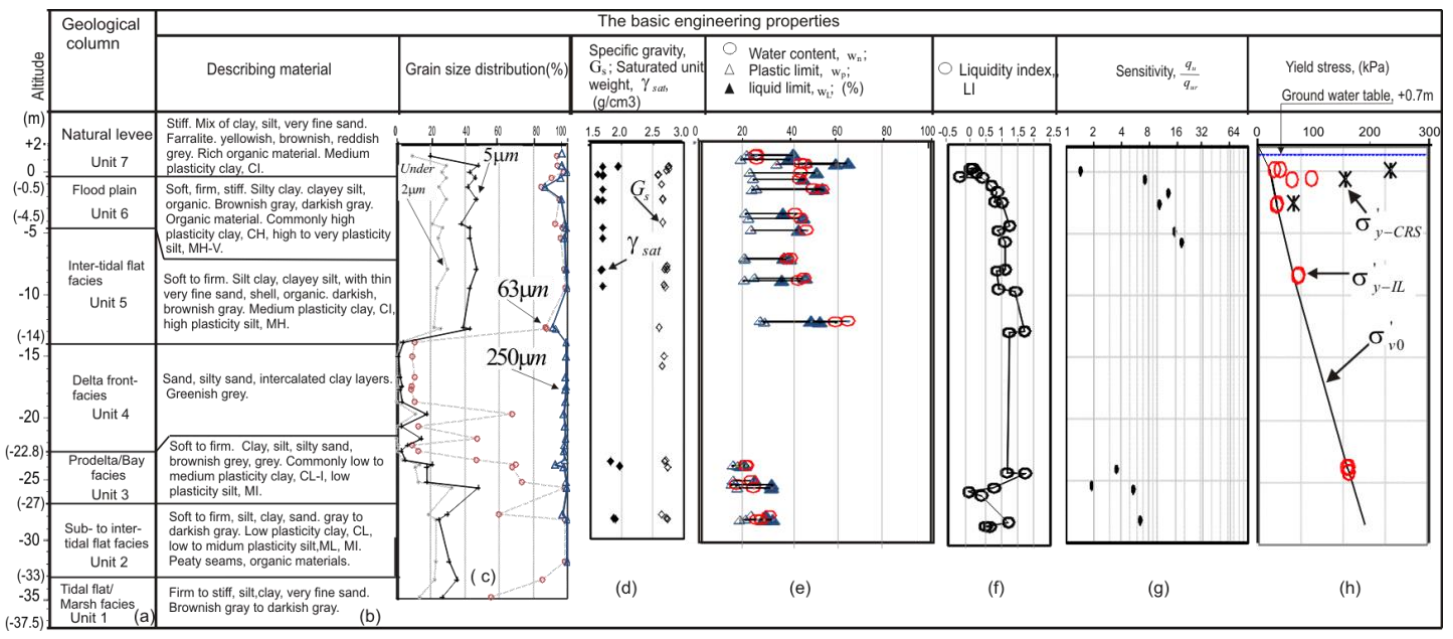

Fig. 5. Summary of lab test results of Caolanh site: (a) Geological column of the CLM1 core, (b) Description of the materials, (c) Grain size distribution, (d) Saturated unit weight $\gamma_{\text {sat }}$ and specific gravity $\mathrm{G}_{\mathrm{s}}$, (e) Natural water content $\mathrm{w}_{\mathrm{n}}$, plastic limit $\mathrm{w}_{\mathrm{p}}$, liquid limit $\mathrm{w}_{\mathrm{L}}$, (f) Liquidity index LI, (g) Sensitivity, ratio of compression strength for undisturbed sample $\mathrm{q}_{\mathrm{u}}$ to remould sample $\mathrm{q}_{\mathrm{ru}}$, (h) Yield stress from IL oedometer test $\sigma_{y-I L}$ and CRS test $\sigma_{y-C R S}^{\prime}$, with vertical effective overburden stress $\sigma_{v 0}^{\prime}$.

\section{Trang 34}




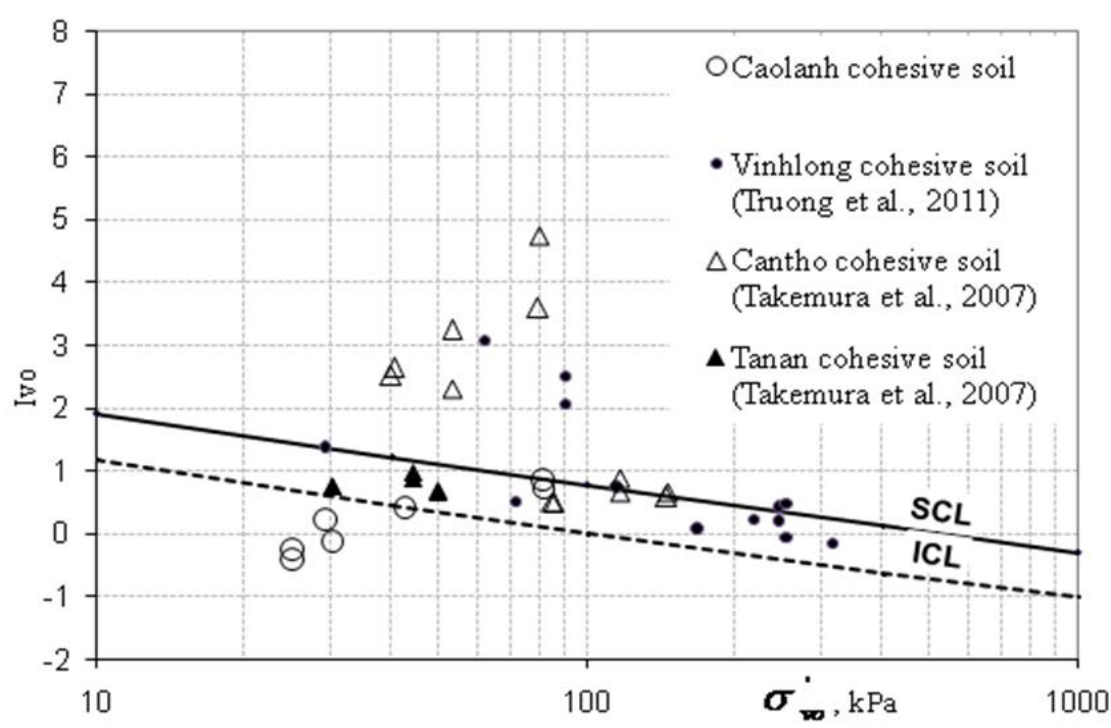

Fig. 6. Relationship between void indices $I_{\mathrm{vo}}$ and effective overburden stress $\sigma_{v o}^{z}$ on the Caolanh, with data of Vinhlong cohesive soils (Truong et al., 2011), Cantho and Tanan cohesive soils (Takemura et al., 2007) [11].

\section{DISCUSSION}

The tidal flat/marsh facies, CPTU1-CL results of this facies show a main soil-behaviortype of normally consolidated clay to silty clay (Fig. 3b). The materials are medium plasticity silt, MI, and high plasticity clay $\mathrm{CH}$ (Fig. 5b, e). This shows relative homogeneity levels and correlates with the sedimentary properties. In sub- to intertidal flat facies, CPTU1-CL results of this facies revealed that $\mathrm{q}_{\mathrm{t}}, \mathrm{u}_{2}$, and $\mathrm{f}_{\mathrm{s}}$ are rather constant with depth and that the soil-behaviortype is only normally consolidated clay to silty clay (Fig. 3b); materials are low to medium plasticity silts, ML, MI (Fig. 5b). In prodelta/bay faices, materials are commonly low plasticity silt, ML, medium plasticity clay, CI, a little CL; CPTU1-CL results, the soil-behavior-types are commonly clay to silty clay, and sand mixtures and silt mixtures.

In delta-front facies, CPTU1-CL results, soilbehavior-types complexly varied (Fig. 3b). Behavior-types mainly tend to be cohesionless soils. $\mathrm{q}_{\mathrm{t}}, \mathrm{u}_{2}$, and $\mathrm{f}_{\mathrm{s}}$ are show saw-tooth graphs with large variations and the largest among all

the facies. These results are correlative with the sedimentary properties. The marked variation of delta front facies in the CLM1 core is the same as these of the Vinhlong site [12].

In intertidal flat facies, the results of CPTU1CL showed that $q_{t}, u_{2}$, and $f_{s}$ are linear with depth. The soil-behavior-types are almost claysclay to silty clay, and a little is organic soils-peats (Fig. 3); materials are high plasticity silt, MH. In flood plain facies, soil-behavior-type is only clays-clay to silty clay; materials are medium and high plasticity clay, CI, CH. The intertidal and flood plain facies are high homogeneous; their formatted sequence is approximate to the sedimentary structure (Fig. 3). Values of $\mathrm{N}$ from SPT did not vary with depth in both sedimentary facies (Fig. 3f).

In the dry season in the tropical area, this sediment layer laid perfectly above the surface water level during a long time. Hence, $\sigma_{y-I L}$ and $\sigma_{y-C R S}$ are so high, the values of $\mathrm{N}$ from the SPT-CL also increased highly (Figs. 5f). Consolidation of the natural levee sediment was 
not by gravitational compaction. This is a special process of consolidation that resulted in values $\mathrm{I}_{\mathrm{v} 0}$ are below the ICL and the smallest in comparison with those of the other facies in the all different sites (Fig. 6).

\section{CONCLUSION}

- The CLM1 core site which include marsh/tidal flat, sub- to intertidal flat, prodelta/bay, delta front, intertidal flat, flood plain, and natural levee facies; they directly overlaied on the undifferent Pleistocene.

- The results indicate that each sedimentary facies presents the typical sequences of the geotechnical properties. Can estimate the trend of mechanical behavior of the Caolanh late Pleistocene-Holocene sediments, MRD.

- The post-depositional processes influence significantly on the formation of the geotechnical properties. Specially, for the natural levee facies, the yield stress $\sigma_{y-I L}$ and $\sigma_{y-C R S}$ increased highly; the yield stress ratios OCRs are the largest in comparison with the other facies; values $I_{v 0}$ are below the ICL. OCRs are always lightly greater than unity in the all facies.

ACKNOWLEDGEMENTS: The authors would like to thank the Port and Airport Research Institute at Yokosuka, Japan, the Civil Engineering Department-Tokyo Tech (TIT) created favorable conditions in which to conduct the lab tests and collect documents, the Faculty of Science and Technology-University of Science Hochiminh City, the Japan Society for the Promotion of Science for its encouragement and finance.This research is funded by Vietnam National University HoChiMinh City (VNU-HCM) under grant number C2014-18-03.The study was also supported partly by the NAFOSTEDED Vietnam project 105.01-2012.25. Mr. K. K. Chen, TIT, collaborated in conducting the tests, the TEDI South, assisted in field tests.

\section{Tướng trầm tích Holocene-Pleistocene muộn và những thuộc tính địa kỹ thuật của lõi khoan CLM1 tại cao lãnh, đồng bằng sông Cửu Long}

- Trương Minh Hoàng

Trường Đại học Khoa học Tự nhiên, ĐHQG-HCM

- Nguyễn Văn Lập

- Ta Thị Kim Oanh

Viện Địa lý Tài nguyên

- Takemura Jiro

Viện Công nghệ Tokyo, Nhật bản

\section{TÓM TÁT}

Mục đích của nghiên cứu là biết được xu hướng ứng xử co học và thuộc tính địa kỹ thuật. Ứng dụng trong tính toán ứng xử co tầng, đặc biệt hệ thống giao thông và cảng, và xây dựng quy trình khảo sát thích hợp kết hợp lấy mẫu, thí nghiệm hiện trường, và học của nền móng; cho quy hoạch cơ sở hạ trong phòng. Thiết lập lại môi trường trầm Trang 36 
tích của lõi khoan CLM1 tại Cao Lãnh, Đồng Bằng Sông Cửu Long dựa trên thuộc tính trầm tích. Khảo sát thuộc tính địa kỹ thuật và nguồn gốc hình thành. Vị trí CLM1 có bảy tướng; mỗi tướng có chuỗi thuộc tính địa kỹ thuật đặc trưng. Quá trình sau trầm tích có vai trò quan trọng trong việc hình thành thuộc tính địa kỹ thuật.

Từ khóa: Pleistocene, Holocene, trầm tích, tướng, đê tự nhiên, thuộc tính địa kỹ thuật, ứng xử cơ học.

\section{REFERENCES}

[1]. T.K.O. Ta, V.L. Nguyen, M. Tateishi, I. Kobayahi, Y. Saito, T. Nakamura, Sediment facies and Late Holocene progradation of the Mekong River Delta in Bentre Province, southern Vietnam: an example of evolution a tide-dominated to a tide- and wavedominated delta, Sedimentary Geology, 152, 313-325 (2002).

[2]. T.K.O. Ta, V.L. Nguyen, M. Tateishi, I. Kobayahi, S. Tanabe, Y. Saito, Holocene delta evolution and sediment discharge of the Mekong River, Southern Vietnam, Quaternary Science Reviews 21, 1807-1819 (2002).

[3]. T.M. Bui, Initial estimation consolidation characteristics of soft Mekong Delta clay for engineering practice, Proc. Intn. Workshop of Hanoi Geoengineering 2003 and 2004, 3749 (2003).

[4]. J.B. Burland, On the compressibility and shear strength of natural clays, Geotechnique 40, 3, 329-378 (1990).

[5]. T.H. Wu, Geotechnical properties of glacial lake clays, Proc. Am. Soc. Civ. Engrs 84, SM3, 1732 (1958).

[6]. K.H. Head, Soil classification and compaction tests, 1, Pentech press London (1985a).
[7]. K.H. Head, Permeability, Shear Strength and Compressibility Tests, 2, Pentech press London, 581-729 (1985b).

[8]. P.K. Robertson, Soil classification using the cone penetration test, Canadian Geotechnical Journal, 27, 151-158 (1990).

[9]. P.K. Robertson, Soil classification using the cone penetration test: Reply, Canadian Geotechnical Journal, 28, 176-178 (1991).

[10].A. Andresen, P. Kolstad, The NGI 54 samplers for undisturbed sampling of clays and representative sampling of coarser materials, Proc. Intn. Sympo, Soil Sampling, Singapore: 13-21 (1979).

[11].J. Takemura, Y. Watabe, M. Tanaka, Characterization of alluvial deposits in Mekong Delta, Proc. Int. Workshop Characterization and Engineering Properties of Natural Soils, 3, 1805-1829 (2007).

[12].M.H. Truong, V.L. Nguyen, T.K.O. Ta, J. Takemura, Changes in late PleistoceneHolocene sedimentary facies of the Mekong River Delta and the influence of sedimentary environment on geotechnical engineering properties, Elsevier, Engineering Geology, 122, 146-159 (2011). 